\title{
WINTER POPULATIONS OF WAXWINGS IN IDAHO
}

\author{
DANIEL M. TAYLOR, 3115 S.E. $8^{\text {th }}$ Avenue, Portland, Oregon 97202; \\ wt@teleport.com
}

\begin{abstract}
I explored the winter distributions of the Cedar Waxwing (Bombycilla cedrorum) and Bohemian Waxwing (B. garrulus) in Idaho by means of the results of Christmas Bird Counts from 1980 to 2016. In northern Idaho the Bohemian was significantly more abundant, but in southern Idaho its numbers declined significantly, as the frequency of large-scale irruptions dropped. Annual variability in the Bohemian Waxwing was significantly greater than that of the Cedar in both regions of Idaho. In neither species was variation in the two regions correlated. In southern Idaho numbers of the Cedar Waxwing decreased with elevation while that of the Bohemian increased. Both species were more numerous in count circles that include mountain slopes than in those consisting of valley floors only, a preference stronger in the Cedar Waxwing than in the Bohemian. A positive correlation between the Cedar Waxwing's abundance and the size of the human population in southern Idaho suggests an effect of ornamental plants. In neither species in neither region did I find a correlation between the birds' abundance and mean temperature in November or December. Limited data on the annual variability in the production of wild fruit in northern Idaho showed no significant correlations with waxwing numbers in that region.
\end{abstract}

The Cedar Waxwing (Bombycilla cedrorum) and Bohemian Waxwing (B. garrulus) often form large nomadic flocks in winter. They are highly variable in numbers and occurrence from year to year, lacking philopatry (Witmer 2002, Witmer et al. 2014). This nomadic behavior is tied to their winter diet, which consists almost exclusively of sugary fruits. Waxwings search over wide areas for such fruits, and large flocks can deplete them quickly (Witmer 2002, Witmer et al. 2014).

Waxwings' winter demographics, interspecific interactions, and relations to fruit availability are poorly understood. Witmer (2002) and Witmer et al. (2014) recommended studies to clarify the demographics of annual variation, how wintering Bohemian and Cedar Waxwings interact and influence one another, and their response to food on large geographic scales. The effects of climate and elevation on wintering waxwings are unstudied.

The winter population dynamics and trends of the waxwings in Idaho are unknown. Larrison et al. (1967:171-172) considered both species highly variable in winter in southern Idaho. Statewide, Burleigh (1972:312-315) considered them unpredictable or irregular.

To clarify the status and ecology of wintering waxwings in Idaho, I examined Christmas Bird Count (CBC) data and other data. Specifically, I addressed the following questions:

Were there significant upward or downward population trends in either species in Idaho from 1980 to 2016 ?

Was one species consistently more abundant or more variable from year to year than the other?

Were annual variations in the two species' numbers correlated at a statewide or local scale?

Were the Cedar and Bohemian Waxwings' winter distribution influenced by elevation or topography? 
Did early winter temperatures affect the abundance of waxwings?

Did fruit productivity or availability influence the waxwings' abundance?

\section{METHODS}

\section{Study Area}

I analyzed $\mathrm{CBC}$ data from 11 circles in southern Idaho and 6 in northern Idaho (Figure 1). Only one circle in central Idaho, the Salmon CBC, was covered during the interval encompassed by my study. It was limited in number of years and level of participation, so I excluded it from analysis. I ascertained the elevation of each circle's center point (Table 1). In southern Idaho, the Snake River Plains gradually rise from west to east, so the CBC circles in

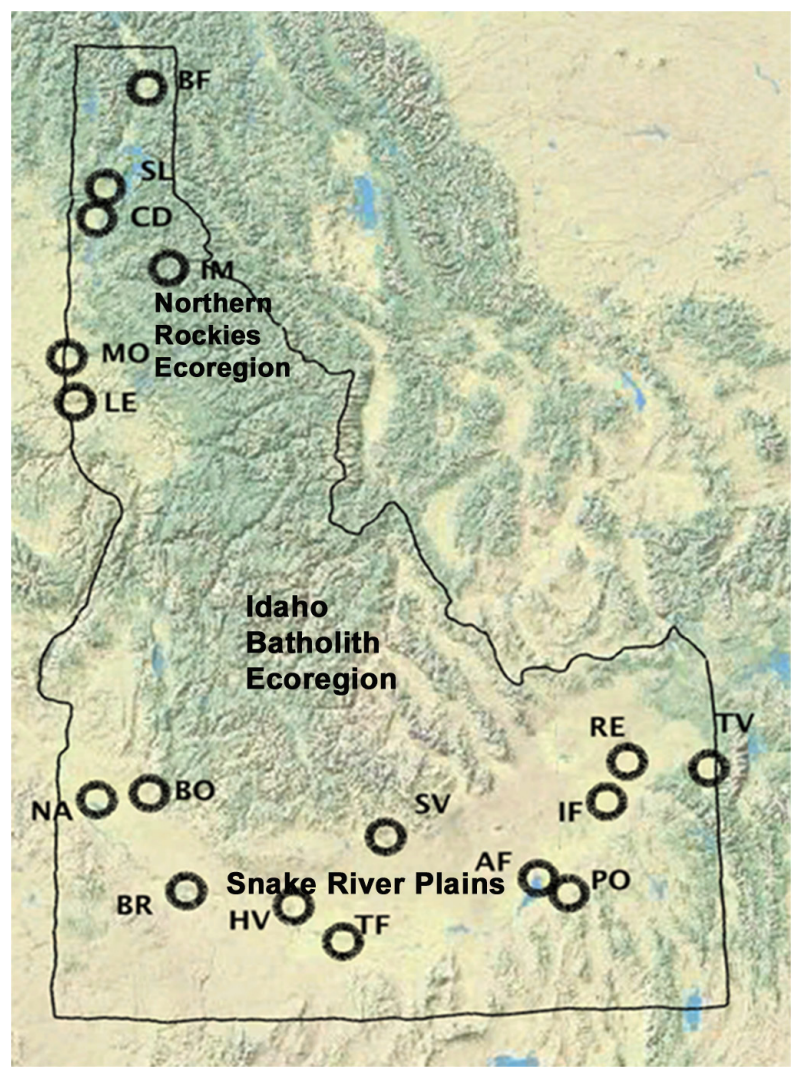

FIgure 1. Christmas Bird Count circles serving as the basis for analysis of the distribution of the waxwings in Idaho. BF, Bonner's Ferry; SL, Spirit Lake; CD, Coeur d'Alene; IM, Indian Mountain; MO, Moscow; LE, Lewiston; NA, Nampa; BO, Boise: BR, Bruneau: HV, Hagerman Valley; TF, Twin Falls; SV, Sun Valley; AF, American Falls; PO, Pocatello; IF, Idaho Falls; RE, Rexburg; TV, Teton Valley. 
TABle 1 Idaho Christmas Bird Counts' Center Points and Their Elevations

\begin{tabular}{lccc}
\hline Count & Latitude $\left({ }^{\circ} \mathrm{N}\right)$ & Longitude $\left({ }^{\circ} \mathrm{W}\right)$ & Elevation $(\mathrm{m})$ \\
\hline Southern Idaho & & & \\
$\quad$ Nampa & 43.568 & 116.673 & 770 \\
Bruneau & 42.925 & 115.858 & 780 \\
Boise & 43.618 & 116.200 & 830 \\
Hagerman Valley & 42.817 & 114.900 & 900 \\
Twin Falls & 42.557 & 114.463 & 1140 \\
American Falls & 42.983 & 112.700 & 1350 \\
Pocatello & 42.868 & 112.430 & 1360 \\
Idaho Falls & 43.517 & 112.060 & 1430 \\
Rexburg & 43.797 & 111.858 & 1480 \\
Sun Valley & 43.308 & 114.067 & 1810 \\
Teton Valley & 43.723 & 111.111 & 1860 \\
Northern Idaho & & & \\
Lewiston & 46.414 & 116.952 & 320 \\
Bonner's Ferry & 48.699 & 116.318 & 580 \\
Coeur d'Alene & 47.738 & 116.788 & 670 \\
Spirit Lake & 47.966 & 116.708 & 720 \\
Moscow-Pullman & 46.731 & 117.040 & 790 \\
Indian Mountain & 47.383 & 116.083 & 1160 \\
\hline
\end{tabular}

this region range in average elevation from $767 \mathrm{~m}$ at Nampa in the west to $1830 \mathrm{~m}$ at Tetonia in the east. Northern Idaho circles were generally lower in elevation, ranging from $310 \mathrm{~m}$ at Lewiston to $1160 \mathrm{~m}$ at Indian Mountain.

The counts in southern Idaho were primarily in the Snake River Plains ecoregion, although the Sun Valley count borders the Idaho batholith ecoregion (EPA 2018). Formerly, the vegetation of southern Idaho was dominated by sagebrush (Artemisia tridentata) and grass with strings of riparian cottonwood (Populus spp.) and willow (Salix spp.) on the Snake River Plains (Tisdale 1986). Much of this native sagebrush has been replaced by either farmland or by exotic species, particularly cheat grass (Bromus tectorum) (Dixon and Johnson 1999). Mountain slopes in southern Idaho count circles are vegetated with belts of Utah juniper (Juniperus osteosperma), patches of coniferous forest, primarily of Douglas fir (Pseudotsuga menziesii), and shrubs. The mountain shrub community includes many fruit-bearing species such as snowberry (Symphoricarpos spp.), currant (Ribes spp.), buckbrush (Ceanothus spp.), serviceberry (Amelanchier alnifolia), elderberry (Sambucus spp.), bitter cherry (Prunus emarginata), mountain ash (Sorbus spp.), and chokecherry (Prunus virginiana) (Tisdale 1986).

Northern Idaho circles lie primarily in the Northern Rockies ecoregion (EPA 2018), consisting of low mountains forested with conifers including Douglas fir, ponderosa pine (Pinus ponderosa), western white pine (P. monticola), western hemlock (Tsuga heterophylla), grand fir (Abies grandis), and western red-cedar (Thuja plicata) (Tisdale 1986, EPA 2018). The native vegetation also includes mountain shrub communities and cottonwood/willow riparian forests. The Lewiston count circle lies completely within, and the Moscow-Pullman circle borders, the Columbia Plateau (EPA 2018), whose 
vegetation resembles that of the Snake River Plains. Because of the ecological and physiographic differences between northern and southern Idaho, I considered them separately for most analyses.

Analyses

I used the number of birds per party-hour as the basis for my analyses. Factors confounding analysis of trends on the basis of CBC data (Sauer and Link 2002) include unique habitats, hard-to-detect species, and increasing count effort. But the waxwings are not hard to detect, and this study did not include unique habitats. The increase in count effort over time was only moderate. The average number of party-hours on the nine southern Idaho CBCs combined was 42 in the 1980s, 40 in the 1990s, 49 in the 2000s, and 50 in the 2010s.

For most analyses, I used data from nine CBCs in southern Idaho that were done consistently and generally had at least 30 party-hours per count. In considering the effects of elevation and the size of the human population in southern Idaho I also included the Bruneau and Tetonia circles, where counts were run from 1994 to 2016. Consistent data from the six northern Idaho circles are available only from 1999 onward, so I compared the two regions from 1999 to 2016.

I evaluated trends and annual variability on the basis of birds per partyhour in each count circle and over all circles in each region combined. For each region, I summed the number of birds per party-hour for each year and divided by the total number of counts. I also assessed the frequency of each species on the basis of its presence or absence on each count for each year.

To assess differences between the two species in the number of birds per party-hour I used $t$ tests. To assess whether there was a change in waxwing populations over time I analyzed the correlation between the combined CBCs' mean number of birds per party-hour and the year.

To examine whether either waxwing species preferred foothill/mountain landscapes or valley floors, I compared the number of birds per party-hour on two pairs of nearly adjacent counts, Nampa-Boise and American FallsPocatello, where one circle covers valley floor only and the other includes foothills or mountain slopes. For each year, I scored the circle with the greater number of birds per hour as positive, then tallied the scores for each circle and analyzed the results by a chi-squared test.

To assess whether the waxwings' abundance was influenced by elevation in each region, I analyzed the correlation between each CBC's mean number of birds per party-hour and its elevation.

To examine whether the two species' abundances were correlated on an annual basis I compared the number of birds per party hour by year for southern and northern Idaho separately.

I investigated correlations between November and December mean temperatures and the waxwings' abundance on the basis of data from the National Oceanic and Atmospheric Administration at http://w2.weather.gov/ climate/. Because mean monthly temperatures within each region are closely correlated, I used the monthly values of Boise to represent all of southern Idaho and those of Coeur d'Alene to represent northern Idaho.

On the basis of long-term annual monitoring, Kasworm et al. (2017) 

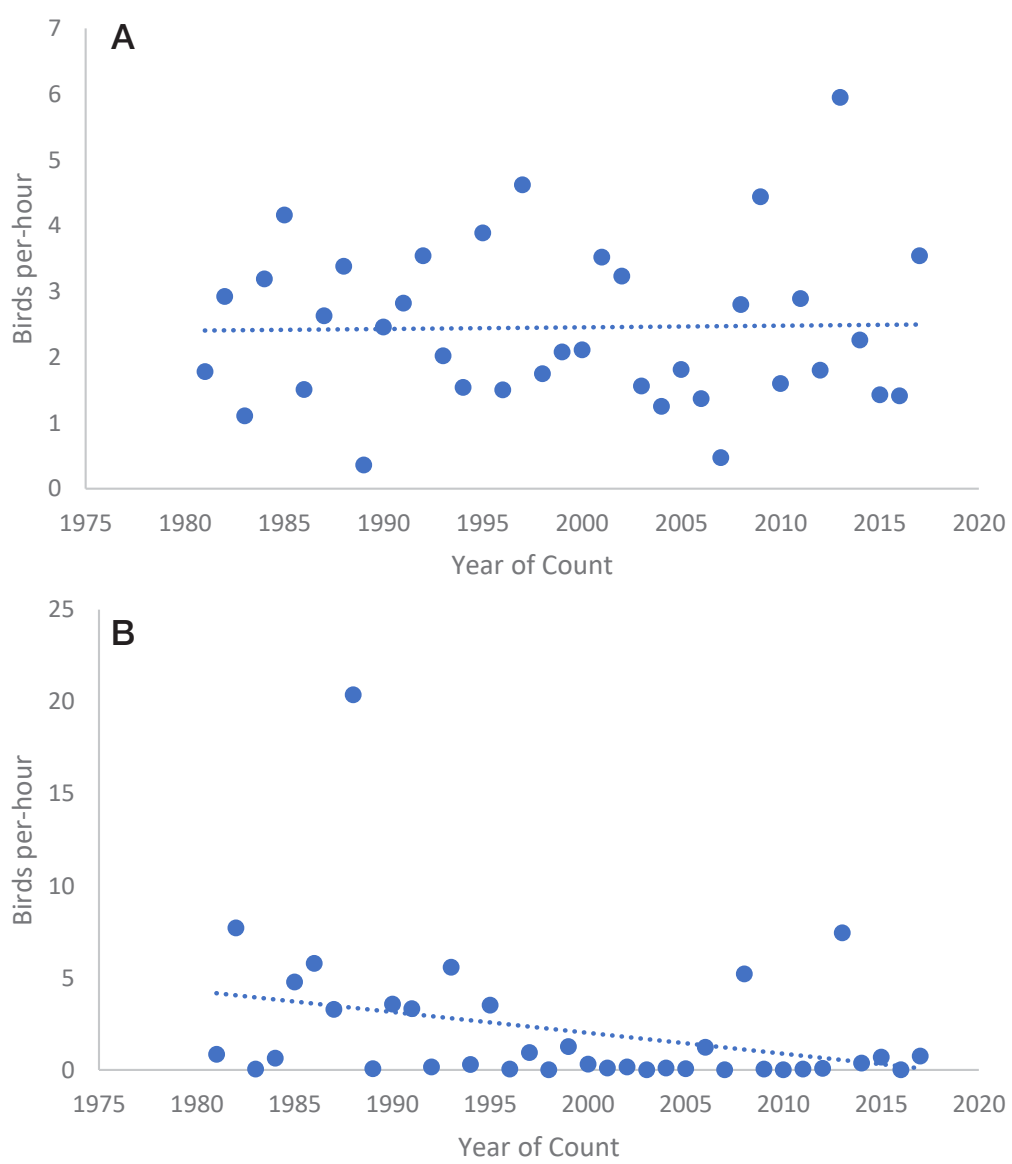

FIGURE 2. Number of waxwings recorded per party-hour on nine combined Christmas Bird Counts in southern Idaho from 1980 to 2016. A, Cedar $(r=-0.02)$; B, Bohemian $(r=-0.32)$.

reported indices of berry productivity of three important wild shrub species in the Cabinet and Yaak mountains of northern Idaho and adjacent Montana. They classified their productivity per year as low, medium, or high. I tested by ANOVA the association between birds per party-hour and the annual berry productivity of each wild shrub. Waxwings are also attracted to the fruits of ornamental trees and shrubs in suburban areas (Witmer 2002, Witmer et al. 2014). In Idaho these include the Russian olive (Elaeagnus angustifolia) (Larrison et al. 1967, Burleigh 1972). Assuming that the number of ornamental shrubs in a CBC circle should be correlated with the circle's human population, I tested for a correlation between waxwing abundance and population size by means of Spearman's rank correlation. To quantify each circle's human population I summed the populations of hamlets and 


\section{WINTER POPULATIONS OF WAXWINGS IN IDAHO}

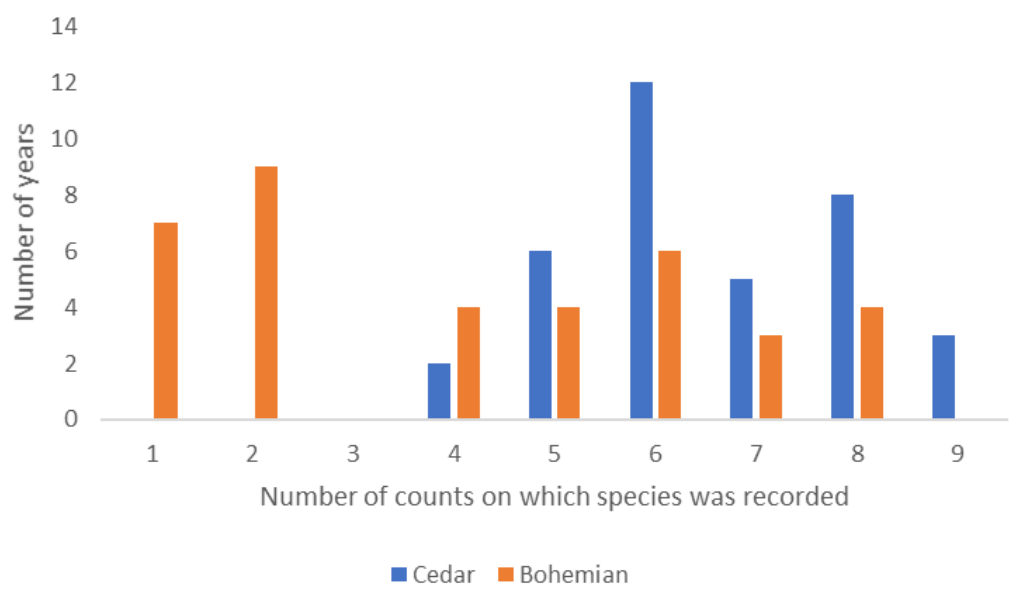

FIGURE 3. Frequency of occurrence of the Cedar and Bohemian Waxwings by number of count circles among nine Christmas Bird Counts in southern Idaho from 1980 to 2016.

towns within it (data extracted from www.factfinder.census.gov/faces/nav/ jsf/pages/community_facts.xhtml?src=bkmk in 2018).

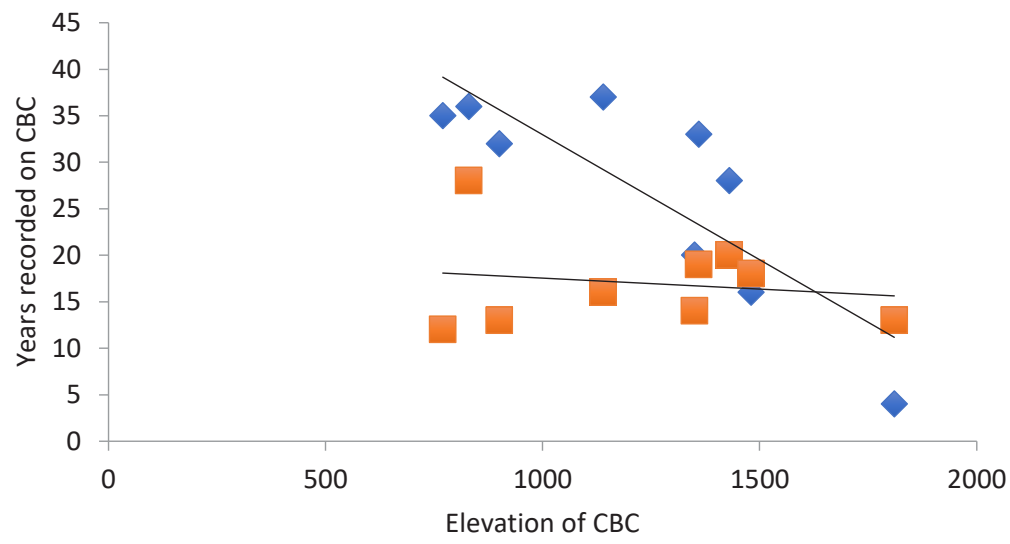

$\rightarrow$ Cedar, $r-0.83^{*} \quad$ Bohemian, $r-0.16$

Figure 4. Frequency of occurrence of the Cedar and Bohemian Waxwings by elevation among nine Christmas Bird Counts in southern Idaho from 1980 to 2016. Blue diamonds, Cedar $(r=-0.83)$; orange squares, Bohemian $(r=-0.16)$. 
TABLE 2 Number of Waxwings per Party-Hour on Nine Southern Idaho Christmas Bird Counts, 1980-2016

\begin{tabular}{|c|c|c|c|c|c|c|c|c|}
\hline \multirow[b]{2}{*}{ Count } & \multicolumn{2}{|c|}{ Range } & \multicolumn{2}{|c|}{ Mean } & \multicolumn{2}{|c|}{ Standard deviation } & \multicolumn{2}{|c|}{$\begin{array}{l}\text { Standard deviation } \\
\text { percent of mean }\end{array}$} \\
\hline & Cedar & Bohemian & Cedar & Bohemian & Cedar & Bohemian & Cedar & Bohemian \\
\hline Nampa & $0-15.73$ & $0-0.92$ & 3.08 & 0.10 & 2.83 & 0.23 & 92 & 230 \\
\hline Boise & $0.2-3.73$ & $0-20.06$ & 5.90 & 1.39 & 5.19 & 3.91 & 88 & 281 \\
\hline $\begin{array}{l}\text { Hagerman } \\
\text { Valley }\end{array}$ & $0-9.54$ & $0-4.17$ & 2.16 & 0.34 & 2.16 & 0.83 & 100 & 244 \\
\hline Twin Falls & $0.20-18.31$ & $0-13.22$ & 4.87 & 0.86 & 4.21 & 2.65 & 86 & 308 \\
\hline American Falls & $0-12.15$ & $0-45.50$ & 1.23 & 5.21 & 2.73 & 12.37 & 222 & 237 \\
\hline Pocatello & $0-11.35$ & $0-60.58$ & 2.35 & 4.71 & 2.87 & 12.55 & 122 & 266 \\
\hline Rexburg & $0-4.00$ & $0-36.50$ & 0.50 & 3.42 & 1.01 & 8.16 & 202 & 239 \\
\hline Idaho Falls & $0-8.87$ & $0-53.53$ & 1.93 & 2.74 & 3.66 & 9.11 & 190 & 332 \\
\hline Sun Valley & $0-1.11$ & $0-6.21$ & 0.04 & 0.41 & 0.18 & 1.42 & 450 & 346 \\
\hline All combined & $0.36-5.95$ & $0.01-20.38$ & 2.45 & 2.13 & 1.22 & 3.84 & 50 & 180 \\
\hline
\end{tabular}

\section{RESULTS}

\section{Abundance and Long-term Trends}

In southern Idaho, on the basis of the means for nine circles from 1980 to 2016 combined and summed (Table 2), the abundance of the Cedar Waxwing $($ mean birds per party-hour $=2.45)$ and Bohemian Waxwing $($ mean $=2.13)$ were similar, not differing significantly $(P=0.76)$. The annual mean was higher for the Cedar than for the Bohemian in 27 of 37 years. In northern Idaho the Cedar appeared less abundant (mean birds per party-hour $=0.79$ ) than the Bohemian (2.60 birds per party-hour) (Table 3). This difference was not quite significant statistically $(P=0.09)$, but when the comparison was restricted to the five higher-elevation circles in northern Idaho (the outlying low-elevation Lewiston $\mathrm{CBC}$ excluded), the difference was significant $(P=$ 0.05 ). The annual mean for the six northern circles summed was higher for the Bohemian Waxwing in 16 of 18 years.

In southern Idaho, numbers of the Cedar Waxwing showed no trend

TABLE 3 Number of Waxwings per Party-Hour on Six Northern Idaho Christmas Bird Counts, 1996-2016

\begin{tabular}{|c|c|c|c|c|c|c|c|c|}
\hline \multirow[b]{2}{*}{ Count } & \multicolumn{2}{|c|}{ Range } & \multicolumn{2}{|c|}{ Mean } & \multicolumn{2}{|c|}{ Standard deviation } & \multicolumn{2}{|c|}{$\begin{array}{l}\text { Standard deviation } \\
\text { percent of mean }\end{array}$} \\
\hline & Cedar & Bohemian & Cedar & Bohemian & Cedar & Bohemian & Cedar & Bohemian \\
\hline Lewiston & $0-2.76$ & 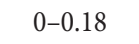 & 0.8 & 0.02 & 0.8 & 0.02 & 114 & 274 \\
\hline Bonner's Ferry & $0-1.08$ & $0-13.33$ & 0.11 & 3.71 & 0.26 & 4.21 & 241 & 113 \\
\hline Coeur d'Alene & $0-1.15$ & $0-7.30$ & 0.28 & 1.69 & 0.38 & 1.84 & 137 & 113 \\
\hline Spirit Lake & $0-0.56$ & $0-10.89$ & 0.08 & 1.34 & 0.15 & 2.56 & 200 & 192 \\
\hline Moscow & $0.13-4.46$ & $0-28.95$ & 0.163 & 6.47 & 1.21 & 8.78 & 75 & 136 \\
\hline $\begin{array}{l}\text { Indian } \\
\quad \text { Mountain }\end{array}$ & $0-8.39$ & $0-8.76$ & 1.82 & 2.20 & 2.43 & 2.82 & 134 & 128 \\
\hline All combined & $0.05-1.71$ & $0.81-8.49$ & 0.79 & 2.60 & 0.56 & 1.88 & 71 & 72 \\
\hline
\end{tabular}


from 1980 to 2016 ( $r=-0.02, P=0.89)$, but those of the Bohemian declined significantly $(r=-0.32, P=0.05)$ (Figure 2$)$. In northern Idaho, neither the Cedar $(r=0.59, P=0.21)$ nor the Bohemian $(r=-0.09, P=0.59)$ showed a significant population trend from 1999 to 2016.

\section{Annual Variability}

In both species variability from year to year was high. In southern Idaho the Bohemian Waxwing was far more variable than the Cedar Waxwing in data for all nine circles combined and on almost all individual counts. For the Bohemian, the standard deviation divided by the mean for all nine circles combined was 3.6 times greater than for the Cedar (Table 2). It was higher, usually considerably so, in all individual circles except for the outlying Sun Valley CBC. In both regions, large irruptions were much more likely in the Bohemian than in the Cedar. In southern Idaho, data from all nine circles combined, the number of birds per party-hour of the Cedar Waxwing exceeded 5 in only a single year and reached a maximum of only 5.95 , while that of the Bohemian Waxwing exceeded 5 in 6 years and reached a maximum of 20.38 (Table 2). Similarly, numbers of the Bohemian in southern Idaho were much more likely to swing low. For the Cedar Waxwing, the lowest number of birds per party-hour for the nine combined counts was 0.36 , whereas for the Bohemian Waxwing it was 0.01 (Table 2). In 12 of the 37 years the number for the Bohemian was less than 0.10 .

Spatially, the Cedar Waxwing was more consistent as well, always being recorded on at least four of the nine southern Idaho counts and occasionally on all nine (Figure 3 ). In contrast, the Bohemian most frequently occurred on only one or two counts, never on all nine (Figure 3). The Cedar occurred more frequently than the Bohemian except in the two circles highest in elevation (Figure 4). The mean number of years that a southern Idaho count recorded the Cedar Waxwing was 26.7 out of 37, almost 10 more than the Bohemian (mean 17.0 years). Even in irruption years counts often missed the Bohemian Waxwing.

The waxwings' levels of annual variability on the six northern Idaho counts resembled those in southern Idaho (Table 3). In most years both species occurred on three to five of the six counts (Figure 5). In northern Idaho the variability in abundance and frequency of occurrence the two species was very similar. The Bohemian Waxwing occurred in larger numbers overall on all counts except for Lewiston and on all counts combined, and only it experienced large-scale irruptions.

\section{Variation by Elevation}

On the nine southern Idaho counts with data from 1980 to $2016(r=-0.74$, $P=0.014)$, as well as on the 11 with data from 1994 to $2016(r=-0.85, P=$ 0.001 ), there was a significant negative correlation between the mean number of Cedar Waxwings per party-hour and elevation. On an annual basis, this correlation with elevation was negative in every year from 1994 to 2016, significantly so in 10 years. There was also a significant negative correlation $(r=$ $-0.83, P=0.006$ ) between the frequency Cedar Waxwings were recorded on a $\mathrm{CBC}$ and the circle's elevation in southern Idaho (Figure 4). Cedar Waxwings 


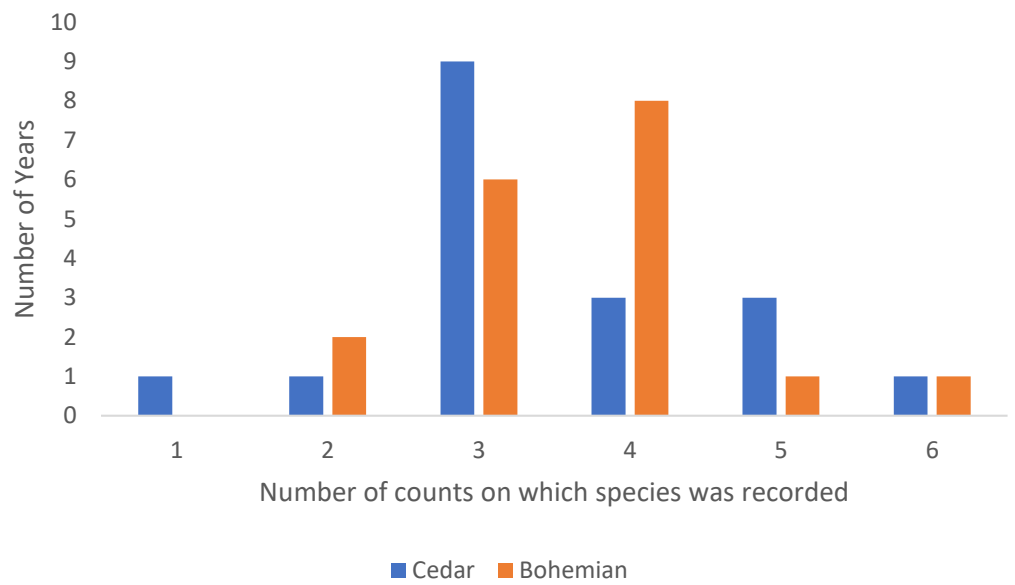

FIGURE 5. Frequency of occurrence of the Cedar and Bohemian Waxwings by number of count circles among six Christmas Bird Counts in northern Idaho from 1999 to 2016.

were recorded annually at Twin Falls and almost annually on the three other lowest counts but were infrequent on the two counts at highest elevations.

Conversely, numbers of the Bohemian Waxwing in southern Idaho tended to increase with elevation. This correlation was not significant for the nine counts combined from 1980 to $2016(r=0.38, P=0.36)$ but was for the 11 combined from 1994 to $2016(r=0.67, P=0.02)$. On an annual basis, the Bohemian Waxwing's correlation with elevation was positive in 21 of 23 years but significantly so in only two years. The number of years that Bohemian Waxwings occurred on a count and the elevation of the count circle showed a no correlation $(r=-0.16, P=0.67)$ (Figure 4$)$.

The more limited northern Idaho data revealed no significant correlations between elevation and abundance of either the Cedar $(r=0.59, P=0.21)$ or the Bohemian $(r=-0.09, P=0.53)$. Neither was there a significant correlation in either species between frequency of occurrence in a given year and elevation in northern Idaho (Cedar, $r=0.05, P=0.92$; Bohemian, $r=0.58, P=0.23$ ).

\section{Correlations between Species and Regions}

Numbers of the Cedar and Bohemian Waxwings were moderately significantly correlated $(r=0.33, P=0.04)$ on the nine southern Idaho CBCs combined, but there was no such correlation $(r=0.06, P=0.49)$ on the six northern Idaho counts. In neither waxwing species were numbers on the combined southern counts in a given year correlated with those on the six northern counts (Cedar, $r=0.17, P=0.48$; Bohemian, $r=0.03, P=0.89$ ).

\section{Correlations with Topography}

The Boise-Nampa and the Pocatello-American Falls CBCs are two pairs of nearby circles (Figure 1). The Boise and Pocatello circles are centered near the 
bases of mountains and include mountains, while the Nampa and American Falls circles are in the middle of the Snake River Plains and lack significant hills or mountains. The number of Bohemian Waxwings per party-hour on a count was significantly more likely to be higher in the Boise circle than in the Nampa circle $(P=0.001)$, but there was no difference between the Pocatello and American Falls circles $(P=0.26)$. But the number of Cedar Waxwings was significantly more likely to be higher in a given year in both circles with mountain slopes (Boise vs. Nampa, $P=0.025$; Pocatello vs. American Falls, $P=0.001$ ).

\section{Correlations between November and December Temperatures} and Waxwing Abundance

In southern Idaho I found no correlation between mean November temperature and number of birds per party-hour for either species (Cedar, $r=$ $0.21, P=0.22$; Bohemian, $r=0.03, P=0.83$ ) or between mean December temperature and waxwing abundance (Cedar $r=0.03, P=0.89$; Bohemian $r-0.07, P=66$ ). For neither species was there any such correlation between northern Idaho temperatures in November (Cedar, $r=0.20, P=23$; Bohemian, $r=0.03, P=0.84$ ) or December (Cedar, $r=-0.22, P=0.20$; Bohemian, $r-0.16, P=0.35$ ) and abundances in southern Idaho. For neither species was there a correlation between mean northern Idaho temperature in November (Cedar, $r=0.06$. $P=0.83$; Bohemian, $r=0.31, P=0.23$ ) or December (Cedar, $r=-0.11, P=0.67$; Bohemian, $r=-0.13, P=0.83$ ) with waxwing abundance in northern Idaho.

\section{Correlation between Abundance of Waxwings}

and Production of Wild Fruit in Northern Idaho

On the basis of results from the six northern Idaho CBCs from 1999 to 2016 combined, I found no significant correlation between the abundance of either waxwing species and productivity of fruits of Amelanchier (Cedar, $P=0.74$; Bohemian, $P=0.43$ ), Sorbus (Cedar, $P=0.11$; Bohemian, $P=0.23$ ) or Vaccinium (Cedar, $P=0.76$; Bohemian, $P=0.42$ ).

\section{Correlation between Human Population}

of a CBC Circle and Waxwing Abundance

When I compared the human population in the southern Idaho CBC circles with waxwing abundance, I found a barely significant positive correlation ( $r=0.62, P=0.05)$ for the Cedar Waxwing when the comparison was based on nine circles from 1980 to 2016, but not when it was based on 11 circles from 1994 to $2016(r=0.25, P=0.76)$. Abundance of the Bohemian Waxwing in southern Idaho was not correlated with human population in either comparison (1980-2016, $r=-0.18, P=0.33$; 1994-2016, $r=-0.11, P>0.50)$.

\section{DISCUSSION}

The great variability in numbers of waxwings and the limited sampling of the CBC impede understanding of these species' distributions, but some clear patterns emerged from these long-term data. Since 1980, numbers of the Bohemian Waxwing in southern Idaho have declined significantly. This 
decline is consistent with Niven et al. (2004) finding a negative trend in CBCs in the Great Basin region from 1965 to 2003. In contrast, Contreras (1997:203-204) reported a modest positive trend from all of Idaho CBCs from 1959 to 1988 . This disparity reflects a decrease in the frequency of invasions of the Bohemian Waxwing into southern Idaho in recent decades. The mean number of Bohemian Waxwings per party-hour for the nine southern Idaho circles combined exceeded 3 in 9 of the 15 years from 1980 to 1994 but in only 2 of the 22 years from 1995 to 2016.

Variation in the Bohemian Waxwing is clearly much greater than that in the Cedar. In southern Idaho, the Bohemian swings from nearly complete absence in some years to infrequent massive irruptions. In contrast, occurrence of the Cedar is more consistent and its peaks are modest. The Cedar Waxwing breeds throughout southern Idaho, so if some birds remain year round they may partially mask the variability in winter visitors. The Bohemian Waxwing breeds only rarely in extreme northern Idaho (Taylor 1918, Larrison et al. 1967:171-172, Burleigh 1972:312-315, Stephens and Sturts 1991). Though the statuses of the two species in northern Idaho are more similar, the Bohemian is the more abundant and more likely to occur in massive numbers. The overall pattern is that Bohemian Waxwings winter consistently in the coniferous-forest region of northern Idaho and invade the Snake River Plains in large numbers only sporadically, while Cedar Waxwings winter consistently throughout the state.

In southern Idaho, the two species' responses to elevation were opposite, numbers of the Bohemian Waxwing moderately increasing with elevation and those of the Cedar sharply decreasing. Comparison of maps of wintering waxwings at www.eBird.org supports this general pattern of the Cedar Waxwing being much more frequent in the western part and along the southern edge of the Snake River Plains and the Bohemian being more frequent on the higher eastern plains and in the mountains. The Bohemian Waxwing is 3/4 larger by mass than the Cedar and breeds farther north so may be better adapted to colder temperatures.

The moderate but significant correlation in southern Idaho between the two species' annual abundance suggests that both species could be responding to some similar environmental factors. But in northern Idaho there was no such correlation. The complete lack of correlation between northern and southern Idaho in annual abundance of either species implies that their movements in the two regions are independent of one another.

The greatest mean abundance of the Cedar Waxwing on any southern Idaho CBC was at Twin Falls, which is located completely within the Snake River Plains. This contradicts the finding of this species preferring mountain slopes. However, the Twin Falls circle includes the Snake River Canyon, whose slopes are clothed with fruit-bearing shrubs such as Ribes (pers. obs.). The mountain slopes of southern Idaho have more native fruit-bearing plants than do the Snake River Plains, and waxwings may associate slopes with food sources.

The limited data on variation in berry productivity in northern Idaho revealed no significant trend with either waxwing species. More long-term data on fruit productivity from more regions is needed to clarify how waxwings response to this variable food source. The positive correlation of the Cedar 
Waxwing with human population on nine southern Idaho counts suggests the birds' attraction to ornamental fruit-bearing shrubs and trees affects their distribution on a broad scale. The lack of correlation in the more recent data for the 11 southern Idaho counts may reflect the widespread expansion of the Russian olive along the Snake River (Dixon and Johnson 1999), including the sparsely populated Bruneau, Hagerman, and American Falls CBC circles (pers. obs.), where waxwings are known to concentrate (Larrison et al. 1967, Burleigh 1972, Taylor et al. 1999).

More CBCs are being established in central Idaho and at higher elevations, so future analysis of Idaho CBC data should clarify the population dynamics of wintering waxwings further.

\section{ACKNOWLEDGMENTS}

Terrell D. Rich, Charles Swift, and Jon Isacoff aided this paper greatly with their suggestions and editing.

\section{LITERATURE CITED}

Burleigh, T. D. 1972. Birds of Idaho. Caxton, Caldwell, ID.

Contreras, A. 1997. Northwest Birds in Winter. Ore. State Univ. Press, Corvallis.

Dixon, M. D., and Johnson, W. C. 1999. Riparian vegetation along the middle Snake River, Idaho: Zonation, geographic trends, and historical changes. Great Basin Nat. 59:18-34.

Environmental Protection Agency (EPA). 2018. Ecoregions of Idaho; ftp://newftp. epa.gov/EPADataCommons/ORD/Ecoregions/id/id_front.pdf (22 March 2018).

Kasworm, W. F., Radandt, T. G., Teisberg, J. E., Welander, A., Proctor, M., and Cooley, H. 2017. Cabinet-Yaak grizzly bear recovery area 2016 research and monitoring progress report. U.S. Fish and Wild. Serv., Missoula, MT; www. fws.gov/mountain-prairie/es/species/mammals/grizzly/CabYaak2016final.pdf.

Larrison E. J., Tucker, J. L., and Jollie, M. T. 1967. Guide to Idaho birds. J. Ida. Acad. Sci. 5:1-220.

Niven, D.K., Saur, J. R., Butcher, G. S, and Link, W. A. 2004. Christmas Bird Count provides insights into population change in land birds that breed in the boreal forest. Am. Birds 58:10-20.

Sauer, J. R., and Link, W. A. 2002. Using Christmas Bird Count data in analysis of population change. Am. Birds 56:10-14.

Stephens, D. A., and Sturts, S. H. 1991. Idaho Bird Distribution. Idaho Mus. Nat. Hist. Publ. 11:1-76.

Taylor, D. M., Burrup, D., Trost, C. H., and Porth, A. 1999. Birds of the American Falls Reservoir area, Snake River, Idaho. J. Ida. Acad. Sci. 35:1-37.

Taylor, W. P. 1918. Bohemian Waxwing (Bombycilla garrulus) breeding within the United States. Auk 35:226-227; doi 10.2307/4072865.

Tisdale, E. W. 1986. Native vegetation of Idaho. Rangelands 8:202-207.

Witmer, M. C. 2002. Bohemian Waxwing (Bombycilla garrulus), in The Birds of North America (A. F. Poole and F. B. Gill, eds.), no. 714. Birds N. Am., Inc., Philadelphia; doi 10.2173/bna.714.

Witmer, M.C., Mountjoy, D. J., and Elliot, L. 2014. Cedar Waxwing (Bombycilla cedrorum), version 2.0, in The Birds of North American (A. F. Poole, ed.), no. 309. Cornell Lab. Ornithol., Ithaca, NY; doi 102173/bna.309. 